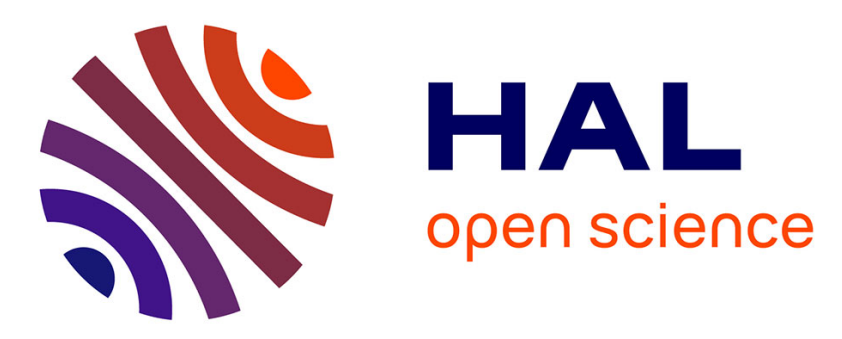

\title{
Microbial bioanodes with high salinity tolerance for microbial fuel cells and microbial electrolysis cells
}

Raphaël Rousseau, Xochitl Dominguez-Benetton, Marie-Line Délia-Dupuy, Alain Bergel

\section{- To cite this version:}

Raphaël Rousseau, Xochitl Dominguez-Benetton, Marie-Line Délia-Dupuy, Alain Bergel. Microbial bioanodes with high salinity tolerance for microbial fuel cells and microbial electrolysis cells. Electrochemistry Communications, 2013, vol. 33, pp. 1-4. 10.1016/j.elecom.2013.04.002 . hal-00875612

\section{HAL Id: hal-00875612 \\ https://hal.science/hal-00875612}

Submitted on 22 Oct 2013

HAL is a multi-disciplinary open access archive for the deposit and dissemination of scientific research documents, whether they are published or not. The documents may come from teaching and research institutions in France or abroad, or from public or private research centers.
L'archive ouverte pluridisciplinaire HAL, est destinée au dépôt et à la diffusion de documents scientifiques de niveau recherche, publiés ou non, émanant des établissements d'enseignement et de recherche français ou étrangers, des laboratoires publics ou privés. 


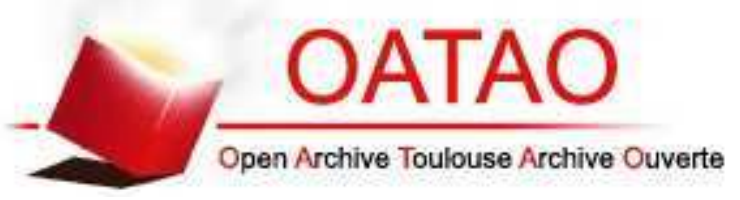

\section{Open Archive TOULOUSE Archive Ouverte (OATAO)}

OATAO is an open access repository that collects the work of Toulouse researchers and makes it freely available over the web where possible.

This is an author-deposited version published in : http://oatao.univ-toulouse.fr/ Eprints ID : 9763

To link to this article : DOI:10.1016/j.elecom.2013.04.002

URL : http://dx.doi.org/10.1016/j.elecom.2013.04.002

To cite this version : Rousseau, Raphael and Dominguez-Benetton, Xochitl and Délia, MarieLine and Bergel, Alain. Microbial bioanodes with high salinity tolerance for microbial fuel cells and microbial electrolysis cells. (2013) Electrochemistry Communications, vol. 33 . pp. 14. ISSN 1388-2481

Any correspondance concerning this service should be sent to the repository administrator: staff-oatao@ listes-diff.inp-toulouse.fr 


\title{
Microbial bioanodes with high salinity tolerance for microbial fuel cells and microbial electrolysis cells
}

\author{
Raphael Rousseau, Xochitl Dominguez-Benetton ${ }^{1}$, Marie-Line Délia, Alain Bergel ${ }^{*}$ \\ Laboratoire de Génie Chimique, CNRS, Université de Toulouse (INPT), 4 allée Emile Monso, BP84234, 31432 Toulouse, France
}

\begin{abstract}
A B S T R A C T
Increasing the conductivity of the electrolytes used in microbial electrochemical systems is an essential prerequisite to the large-scale success of these technologies. Microbial bioanodes formed from a salt marsh inoculum under constant acetate feeding generated up to $85 \mathrm{~A} \cdot \mathrm{m}^{-2}$ in media containing $776 \mathrm{mM} \mathrm{NaCl}$ (45 $\mathrm{g} \cdot \mathrm{L}^{-1}, 1.5$ times the salinity of seawater). These values were the highest salinities accepted by a microbial anode so far and the highest current densities reported with felt graphite electrodes.
\end{abstract}

Keywords:

Bioanode

Microbial anode

Salinity

Microbial fuel cell

Bioelectrochemical system

\section{Introduction}

Microbial electrochemistry has been progressing extremely fast for ten years, resulting in various promising microbial electrochemical technologies such as microbial fuel cells (MFCs) or microbial electrolysis and electrosynthesis cells [1]. The actual development of these technologies depends, to a great extent, on the possibility of designing efficient microbial bioanodes. The performance of a bioanode is controlled by the electrocatalytic properties of the microbial biofilm that develops on its surface, and researchers have consequently focused great attention on optimizing biofilm growth. Unfortunately, most microorganisms do not accept salinities higher than around $100 \mathrm{mM}$ (a few $\mathrm{g} \cdot \mathrm{L}^{-1}$ ). Two opposing goals consequently arise in the development of microbial electrochemical technologies: on the one hand, the salinity of the electrolyte must be as high as possible to decrease the ohmic drop but, on the other hand, it must not exceed the level that microorganisms can tolerate. Liu et al. have illustrated the positive effect of increasing ionic strength: increasing the $\mathrm{NaCl}$ content from 100 to $403 \mathrm{mM}$ increased the power density from 720 to $1330 \mathrm{~mW} \cdot \mathrm{m}^{-2}$ [2]. Lefebvre et al., working in a larger range of $\mathrm{NaCl}$ concentrations, confirmed a similar power increase up to $345 \mathrm{mM} \mathrm{NaCl}$ and then observed the detrimental impact of the highest concentrations, with a $50 \%$ power decrease at $690 \mathrm{mM} \mathrm{NaCl}$ [3].

\footnotetext{
* Corresponding author

E-mail address: alain.bergel@ensiacet.fr (A. Bergel).

1 Present address: Separation and Conversion Technology, Flemish Institute for Technological Research (VITO), Boeretang 200, Mol 2400, Belgium.
}

For this reason, most microbial electrochemical technologies have so far been developed in solutions with low conductivities [2-5] (Table 1). Typically, the higher power densities obtained with MFCs have been around $7 \mathrm{~W} \cdot \mathrm{m}^{-2}[2,6]$ and more commonly of the order of 2 to $3 \mathrm{~W} \cdot \mathrm{m}^{-2}$, for conductivity of the order of $20 \mathrm{mS} \cdot \mathrm{cm}^{-1}$ [1]. In such conditions, producing a current density of $100 \mathrm{~A} \cdot \mathrm{m}^{-2}$ between electrodes $2 \mathrm{~cm}$ apart would induce an ohmic drop of $1 \mathrm{~V}$. This elementary calculation demonstrates that, to be implemented on a large scale, microbial bioanodes must become able to operate at drastically higher conductivities. This is an essential prerequisite if microbial electrochemical technologies are to advance.

The salinity level tolerated by microbial bioanodes can be increased by forming them directly in the sea [7]. Seawater salinity is high, around $5.4 \mathrm{~S} \cdot \mathrm{m}^{-1}$, mainly due to a $\mathrm{NaCl}$ concentration around $517 \mathrm{mM}$, and marine micro-flora is perfectly adapted to functioning in these saline environments. Nevertheless, current densities produced by benthic MFCs remain modest, because of the small amount of biodegradable matter contained in sediments [8]. Recently, You et al. [9] have implemented a marine microbial community in a laboratory MFC used to treat wastewater from a seafood house with a salinity of $759 \mathrm{mM}$. Their results can hardly be compared with others because a graphite granular anode $\left(50 \mathrm{~m}^{2} \cdot \mathrm{m}^{-3}\right)$ was used, but the calculated power density of $826 \mathrm{~mW} \cdot \mathrm{m}^{-2}$ indicated some success.

The purpose of this work was to design microbial bioanodes able to operate in high conductivity electrolytes. In this aim, inoculum samples were collected from a salt marsh with the view to forming halo-tolerant electroactive biofilms. Experiments were conducted in 3-electrode set-ups to avoid the effect of the ohmic drop. In a 3-electrode set-up, the ohmic drop occurs only between the anode (working electrode) and the tip of the reference electrode, and this 
Table 1

Bioanode performance obtained in the present work and reported in the literature dealing with the effect of salinity. ${ }^{*}$ In the case marked by an asterisk, the current was limited by the electronic threshold of the potentiostat.

\begin{tabular}{|c|c|c|c|c|c|c|}
\hline \multirow{2}{*}{$\begin{array}{l}\text { Reference } \\
\text { Lefebvre et al. [3] }\end{array}$} & \multicolumn{2}{|c|}{$\begin{array}{l}\mathrm{NaCl} \text { concentration or ionic strength } \\
(\mathrm{mM})\end{array}$} & \multirow{2}{*}{$\begin{array}{l}\text { Conductivity } \\
\left(\mathrm{mS} \cdot \mathrm{cm}^{-1}\right)\end{array}$} & \multicolumn{2}{|l|}{$\begin{array}{l}\text { Current density } \\
\text { or power density }\end{array}$} & \multirow{2}{*}{$\begin{array}{l}\text { Coulombic efficiency } \\
(\%)\end{array}$} \\
\hline & $\mathrm{NaCl}$ concentration & 86 & & Power density & 31 & \\
\hline & & 172 & 23 & $\left(\mathrm{~W} \cdot \mathrm{m}^{-2}\right)$ & 34 & 34 \\
\hline & & 345 & 47 & & 35 & 28 \\
\hline & & 690 & 94 & & 18 & 22 \\
\hline \multirow[t]{4}{*}{ Liu et al. [2] } & Ionic strength & 100 & 14 & Power density & 720 & 45 \\
\hline & & 200 & 27 & $\left(\mathrm{~W} \cdot \mathrm{m}^{-3}\right)$ & 1000 & 50 \\
\hline & & 300 & 41 & & 1200 & 60 \\
\hline & & 403 & 55 & & 1330 & 61 \\
\hline \multirow[t]{3}{*}{ Feng et al. [4] } & / & / & 3.5 & Power density & 189 & N.C. \\
\hline & & & 5 & $\left(\mathrm{~W} \cdot \mathrm{m}^{-2}\right)$ & 315 & \\
\hline & & & 7 & & 467 & \\
\hline \multirow[t]{3}{*}{ Mohan et al. [5] } & $\mathrm{NaCl}$ concentration & 5 & 0.7 & Power density & N.C. & N.C. \\
\hline & & 10 & 1.4 & $\left(\mathrm{~W} \cdot \mathrm{m}^{-2}\right)$ & 12.8 & \\
\hline & & 15 & 2.0 & & N.C. & \\
\hline \multirow[t]{4}{*}{ Aaron et al. [14] } & Ionic strength & 37 & 5 & Power density & From 378 & N.C. \\
\hline & & 93 & 13 & $\left(\mathrm{~W} \cdot \mathrm{m}^{-2}\right)$ & to 793 & \\
\hline & & 190 & 26 & & & \\
\hline & & 370 & 50 & & & \\
\hline \multirow{3}{*}{$\begin{array}{c}\text { This work } \\
\text { run \#1 }\end{array}$} & $\mathrm{NaCl}$ concentration & 517 & 70 & Current density & $16^{*}$ & 16.9 \\
\hline & & 776 & 104 & $\left(A \cdot m^{-2}\right)$ & 30 & 11.3 \\
\hline & & 1034 & 135 & & 10 & 4.4 \\
\hline \multirow{3}{*}{$\begin{array}{c}\text { This work } \\
\text { run } \# 2\end{array}$} & & 517 & 70 & & 50 & 4.9 \\
\hline & & 776 & 104 & & 45 & 4.4 \\
\hline & & 1034 & 135 & & 30 & 2.4 \\
\hline \multirow{3}{*}{$\begin{array}{c}\text { This work } \\
\text { run \#3 }\end{array}$} & & 517 & 70 & & 65 & 15.8 \\
\hline & & 776 & 104 & & 75 & 12 \\
\hline & & 1034 & 135 & & 33 & 6.3 \\
\hline \multirow{3}{*}{$\begin{array}{l}\text { This work } \\
\text { run \#4 }\end{array}$} & & 776 & 104 & & 85 & 22.7 \\
\hline & & 776 & 104 & & 65 & 24.4 \\
\hline & & 776 & 104 & & 45 & 23.5 \\
\hline
\end{tabular}

distance is kept to a minimum (a few millimeters). It was thus possible to characterize the impact of different salinities on the bioanodes while avoiding the effect of variations in ohmic drop.

\section{Materials and methods}

\subsection{Media}

Sediment was collected from a salt marsh of the Mediterranean Sea (Gruissan, France). At the collection site, the $\mathrm{pH}$ of the water was 6.5 to 7.4 and its conductivity was 7.6 to $12.3 \mathrm{~S} \cdot \mathrm{m}^{-1}$ i.e. up to 2.3 times higher than seawater conductivity $\left(5.4 \mathrm{~S} \cdot \mathrm{m}^{-1}\right)$. The sediments stored at room temperature didn't show any evolution in their capability to produce efficient bioanodes. They were analyzed by selected area electron diffraction (SAED, Oxford detector) with a scanning electron microscope (Leo $436 \mathrm{VP}$ ). Two different inoculum samples were collected and dried and each sample was analyzed in different plots, which gave identical spectra.

The solution used for the electrochemical experiments contained: $\mathrm{NH}_{4} \mathrm{Cl} 2 \mathrm{~g} \cdot \mathrm{L}^{-1}, \mathrm{~K}_{2} \mathrm{HPO}_{4} 0.5 \mathrm{~g} \cdot \mathrm{L}^{-1}$, sodium acetate $40 \mathrm{mM}, \mathrm{HCl}$ $37 \% 46 \mathrm{~mL}, \quad \mathrm{MgCl}_{2} \cdot 6 \mathrm{H}_{2} \mathrm{O} 55 \mathrm{mg} \cdot \mathrm{L}^{-1}, \quad \mathrm{FeSO}_{4}(\mathrm{NH} 4)_{2} \mathrm{SO}_{4} \cdot 6 \mathrm{H}_{2} \mathrm{O}$ $7 \mathrm{mg} \cdot \mathrm{L}^{-1}, \mathrm{ZnCl}_{2} \cdot 2 \mathrm{H}_{2} \mathrm{O} 1 \mathrm{mg} \cdot \mathrm{L}^{-1}, \mathrm{MnCl}_{2} \cdot 4 \mathrm{H}_{2} \mathrm{O} 1.2 \mathrm{mg} \cdot \mathrm{L}^{-1}, \mathrm{CuSO}_{4}$. $5 \mathrm{H}_{2} \mathrm{O} 0.4 \mathrm{mg} \cdot \mathrm{L}^{-1}, \mathrm{CoSO}_{4} \cdot 7 \mathrm{H}_{2} \mathrm{O} 1.3 \mathrm{mg} \cdot \mathrm{L}^{-1}, \mathrm{BO}_{3} \mathrm{H}_{3} 0.1 \mathrm{mg} \cdot \mathrm{L}^{-1}$, $\mathrm{Mo}_{7} \mathrm{O}_{2}(\mathrm{NH} 4)_{6} \cdot 4 \mathrm{H}_{2} \mathrm{O} 1 \mathrm{mg} \cdot \mathrm{L}^{-1}, \mathrm{NiCl}_{2} \cdot 6 \mathrm{H}_{2} \mathrm{O} 0.05 \mathrm{mg} \cdot \mathrm{L}^{-1}, \mathrm{Na}_{2} \mathrm{SeO}_{3}$. $5 \mathrm{H}_{2} \mathrm{O} \quad 0.01 \mathrm{mg} \cdot \mathrm{L}^{-1}$, and $\mathrm{CaCl}_{2} \cdot 2 \mathrm{H}_{2} \mathrm{O} \quad 60 \mathrm{mg} \cdot \mathrm{L}^{-1}$. Solutions were complemented with three different $\mathrm{NaCl}$ concentrations: 517,776 and $1034 \mathrm{mM}\left(30,45\right.$ and $\left.60 \mathrm{~g} \cdot \mathrm{L}^{-1}\right)$ resulting in final conductivities of 70 , 104 and $135 \mathrm{mS} \cdot \mathrm{cm}^{-1}$, respectively.

\subsection{Electrodes and electrochemical procedure}

Anodes were made of carbon felt (Mersen) of $2 \mathrm{~cm}^{2}$ projected surface area and current densities were expressed with respect to this projected surface area. 254SMO grade stainless steel (Outokumpu) was used as the counter-electrode because of its resistance to corrosion in chloride solution. Working and counter-electrodes were connected to the electrical circuit by titanium wires (Alfa Aesar), which were insulated with a heat shrinkable sheath. Saturated calomel electrodes (Radiometer, SCE) were used as references (potential 0.241 V/SHE) and potentials were monitored with a multi-channel potentiostat (Biologic).

Each reactor, equipped with a 3-electrode system, was filled with $50 \mathrm{~mL}$ raw salt marsh sediment and $450 \mathrm{~mL}$ solution. Each reactor was hermetically closed, the $200 \mathrm{~mL}$ headspace was deoxygenated by 20 min nitrogen bubbling and the carbon felt anode (working electrodes) was then polarized at $+0.1 \mathrm{~V} / \mathrm{SCE}$. Each experimental "run" was performed with three independent reactors that were operated in parallel at the same time and inoculated with the same inoculum sample. When the current started to decrease, to prevent any substrate limitation, the acetate concentration was measured (enzyme kit K-ACETAK, Megazyme) and acetate was added to recover the $40 \mathrm{mM}$ initial concentration with a concentrated solution (4 M). Polarization was interrupted from time to time to record cyclic voltammetry curves $(\mathrm{CV})$ at $1 \mathrm{mV} \cdot \mathrm{s}^{-1}$. Three successive cycles were performed. During a cycle the potential of the working electrode was scanned from the value used during polarization to the upper limit of $0.5 \mathrm{~V}$ and then down to $-0.6 \mathrm{~V}$ and finally back to the starting value. The second and third cycle curves were generally perfectly superimposed, so only the third cycle is reported here. All reactors were placed in thermostatic baths maintained at $30^{\circ} \mathrm{C}$. Coulombic efficiencies were calculated by integrating the current and dividing the charge obtained by the theoretical charge of complete oxidation of acetate to $\mathrm{CO}_{2}$ (8 electrons produced per molecule of acetate).

\section{Results and discussion}

Three reactors that contained $\mathrm{NaCl}$ concentrations of 517,776 and $1034 \mathrm{mM}\left(30,45\right.$ and $\left.60 \mathrm{~g} \cdot \mathrm{L}^{-1}\right)$ respectively were run in parallel and the experiment was repeated three times (runs \#1 to 3). A constant 
potential of $+0.1 \mathrm{~V} / \mathrm{SCE}$ was applied because preliminary experiments had shown the best results with this value. The current started to increase after around 2 days for all reactors (Fig. 1). No significant effect of salinity was observed on the initial latency period. For salinities of 517 and $776 \mathrm{mM}$, current densities ranging from 30 to $75 \mathrm{~A} \cdot \mathrm{m}^{-2}$ were reached after 14 days of polarization (Fig. 1, Table 1 , one reactor gave only $16 \mathrm{~A} \cdot \mathrm{m}^{-2}$ but because of electronic limitation). With $1034 \mathrm{mM} \mathrm{NaCl}$, current densities were always lower, in the range of 10 to $33 \mathrm{~A} \cdot \mathrm{m}^{-2}$. Despite significant deviations from one run to the other, a consistent trend was observed: increasing salinity from 517 and $776 \mathrm{mM}$ did not affect the maximum current, but $1034 \mathrm{mM}$ had a clear detrimental effect. The same trend was confirmed by the values of Coulombic efficiencies (Table 1 ).

A fourth experimental run (\#4) performed with three reactors containing $776 \mathrm{mM} \mathrm{NaCl}$ confirmed the very high current densities. The nine reactors operated with $\mathrm{NaCl}$ concentrations of 517 and $776 \mathrm{mM}$ gave current densities ranging from 30 to $85 \mathrm{~A} \cdot \mathrm{m}^{-2}$ with average of $57 \mathrm{~A} \cdot \mathrm{m}^{-2}$ (Table 1 , the value $16 \mathrm{~A} \cdot \mathrm{m}^{-2}$ was not taken into account), while the maximum values reported in the literature with similar carbon felt electrodes were 31 [10] to $35 \mathrm{~A} \cdot \mathrm{m}^{-2}$ [6].

The general shape of the CV was similar for each electrode as illustrated in Fig. 2. The forward scans showed a common shape, which has already been observed with stainless steel and carbon anodes $[11,12]$. The kinetics was far from a Nernstian law, and progress can still be made to improve the electrode/biofilm electron transfer. The
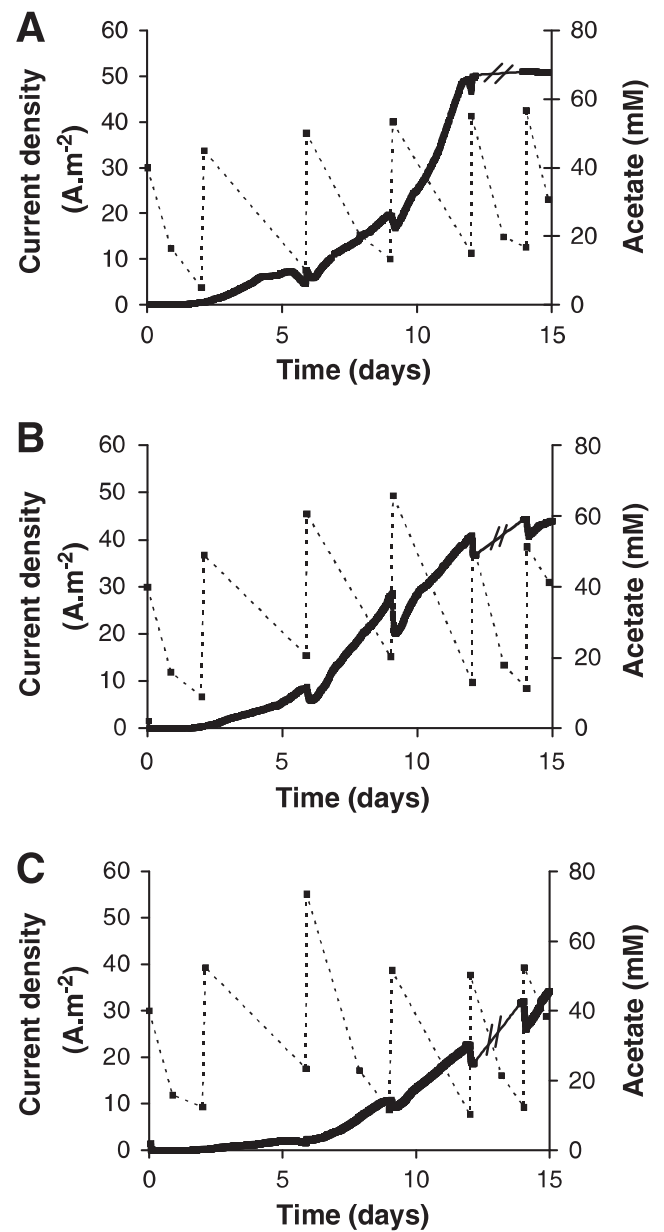

Fig. 1. Current density and substrate concentration versus time during chronoamperometry at $+0.1 \mathrm{~V} / \mathrm{SCE}$ (run \#2) with $\mathrm{NaCl}$ concentrations of 517 (A), 776 (B) and 1034 (C) mM. The dotted lines between the acetate concentration points are intended to make the figure easier to read; they do not reflect the variation in acetate concentration between the measurements.

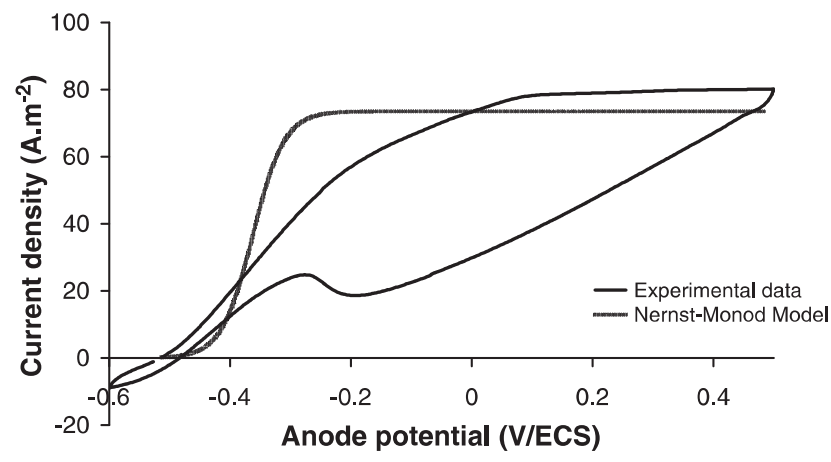

Fig. 2. Cyclic voltammetry recorded at $1 \mathrm{mV} \cdot \mathrm{s}^{-1}$ at the end of the chronoamperometry with the bioanode that gave $85 \mathrm{~A} \cdot \mathrm{m}^{-2}$ (run \#4). The theoretical Nernstian curve (dotted line) was obtained by minimizing the sum of squares of the residuals between the recorded current (forward scan) and the Nernst law.

backward scans always had a more complex shape, with a reduction peak around $-0.2 \mathrm{~V} / \mathrm{SCE}$, superimposed on the expected sigmoid curve. Such a shape has rarely been reported and needs further investigation to be explained.

The procedure implemented here was different from the protocols commonly used to design bioanodes in 3-electrode set-ups. The most common procedure uses successive batches, during which the acetate is consumed completely. The general procedure is to wait for the current to fall to zero before adding a new acetate load or replacing the medium with fresh solution. Usual chronoamperograms are consequently made up of successive current peaks that correspond to the successive acetate additions $[6,10]$. Preliminary experiments performed with this protocol showed that the current fell to zero when acetate was consumed and was then recovered when acetate was added again into the reactor, but the maximum current densities did not exceeding $28 \mathrm{~A} \cdot \mathrm{m}^{-2}$. In contrast, for the experiments described above, care was taken to avoid the current falling to low values, as successfully done in a few studies [13]. At the very beginning of any significant current decrease, acetate was added to bring the concentration back to the initial value of $40 \mathrm{mM}$. The bioanodes were thus never in acetate limitation and the chronoamperograms showed a constant current increase until a plateau was reached (Fig. 1). Also with the objective of favoring high current densities, it was decided to use anodes with small surface area $\left(2 \mathrm{~cm}^{2}\right)$ in a large solution volume $(500 \mathrm{~mL})$ to minimize the depletion of acetate due to electrochemical oxidation.

The results obtained here were less reproducible than the current peaks commonly reported with the usual procedure $[6,10]$. The raw sediment used here certainly suffered from spatially heterogeneous chemical and microbial compositions, which were doubtless a main cause of variation from one reactor to the other. Moreover, a significant amount of inoculum $(10 \% \mathrm{v} / \mathrm{v})$ was used for each reactor, which amplified the impact of any sample heterogeneity. Nevertheless, the limited reproducibility of the current density values did not impact the two main conclusions: high current densities, above the values commonly reported so far, were obtained and the detrimental effect of $1034 \mathrm{mM} \mathrm{NaCl}$ was confirmed in the three experimental runs (\#1 to \#3).

The $50 \mathrm{~mL}$ salt marsh sediment used to inoculate the $500 \mathrm{~mL}$ final volume resulted in rich media that certainly contained a variety of soluble electron acceptors, including sulfate ions and iron oxides for example. SAED analysis of sediment samples revealed that the inoculum contained on average $2.0 \%$ of iron of the total dry mass. The richness of the inoculum in soluble electron acceptors favored alternative reactions for acetate consumption and resulted in low CE values (Table 1). Moreover, the low "surface area/solution volume" ratio minimized the weight of electrochemical oxidation with respect 
to the alternative acetate oxidations. The experimental conditions chosen here to favor high current densities logically led to low CE. In each of the three runs, the increase of the salinity to $1034 \mathrm{mM}$ considerably decreased the CE (up to a factor of 4 for run \#1), indicating that the oxidation pathways that did not use the anode were less affected by high salinity than the anode-respiring pathways.

\section{Conclusion}

By avoiding acetate limitation and using salt marsh sediment as the inoculum, microbial bioanodes were able to give up to $85 \mathrm{~A} \cdot \mathrm{m}^{-2}$ in electrolytes with conductivities of $104 \mathrm{mS} \cdot \mathrm{cm}^{-1}$, corresponding to 1.5 times the salinity of seawater. The current decreased at higher salinity, but $30 \mathrm{~A} \cdot \mathrm{m}^{-2}$ were still produced at two times seawater salinity $\left(135 \mathrm{mS} \cdot \mathrm{cm}^{-1}\right)$.

\section{Acknowledgments}

This work was part of the "DéfiH12" project funded by the French National Research Agency (ANR-09-BioE-010).

\section{References}

[1] B.E. Logan, K. Rabaey, Science 334 (2012) 686-690.

[2] H. Liu, S. Grot, B.E. Logan, Environmental Science and Technology 39 (2005) 4317-4337.

[3] O. Lefebvre, Z. Tan, S. Kharkwal, H.Y. Ng, Bioresource Technology 112 (2012) 336-340.

[4] Y. Feng, X. Wang, B.E. Logan, H. Lee, Applied Microbiology and Biotechnology 78 (2008) 873-880

[5] Y. Mohan, D. Das, International Journal of Hydrogen Energy 34 (2009) 7542-7546.

[6] D. Pocaznoi, B. Erable, L. Etcheverry, M.-L. Delia, A. Bergel, Physical Chemistry Chemical Physics 14 (2012) 13332-13343.

[7] L.M. Tender, C.E. Reimer, H.A. Stecher, D.E. Holmes, D.R. Bond, D.A. Lowy, K Pilobello, S.J. Fertig, D.R. Lovley, Nature Biotechnology 20 (2002) 821-825.

[8] B.E. Logan, Microbial Fuel Cells, John Wiley \& Sons, Inc., Hoboken, New Jersey, 2002. $162-170$

[9] S.J. You, J.N. Zhang, Y.X. Yuan, N.Q. Ren, X.H. Wang, Journal of Chemical Technology and Biotechnology 85 (2010) 1077-1083.

[10] G. He, Y. Gu, S. He, U. Schröder, S. Chen, H. Hou, Bioresource Technology 102 (2011) 10763-10766.

[11] D. Pocaznoi, A. Calmet, L. Etcheverry, B. Erable, A. Bergel, Energy \& Environmental Science 5 (2012) 9645-9652.

[12] L.M. Tender, S.A. Gray, E. Groveman, D.A. Lowy, P. Kauffman, J. Melhado, R.C. Tyce, D. Flynn, R. Petrecca, J. Dobarro, Journal of Power Sources 179 (2008) 571-575.

[13] D.R. Bond, D.R. Lovley, Applied and Environmental Microbiology 69 (2003) $1548-1555$.

[14] D. Aaron, C. Tsourtis, C.Y. Hamilton, A.P. Borole, Energies 3 (2010) 592-606. 